\title{
THE MARKETS OF POTATOES AND SUGAR BEETS IN POLAND BEFORE AND AFTER ACCESSION TO THE EUROPEAN UNION. AN ATTEMPT TO COMPARE
}

\author{
Andrzej Czyżewski, Full Professor'; Dariusz Czakowski, PhD² \\ ${ }^{1}$ Faculty of Economics and Management, University of Zielona Góra \\ ${ }^{2}$ Faculty of Law, Administration and Economics, Kujawy and Pomorze University in Bydgoszcz
}

\begin{abstract}
The article attempts to identify the dynamics and direction of the root plant market development in Poland in the period before and after accession to the European Union by defining resource-efficiency relations related to the cultivation of potatoes and sugar beet. The research was carried out in the years 1994-2016. Based on them, it turned out that despite the progressive process of concentration and specialization of production on the market of root crops in Poland, income efficiency (without subsidies), especially in the case of sugar beets, decreased significantly. In addition, the area of cultivation of both potatoes and sugar beet was systematically decreasing, which was partially compensated by the improvement in crops. As a result of these adjustments, sugar beet harvests were at a similar level throughout the entire period considered, while potato production decreased.
\end{abstract}

Keywords: root crop market, sugar market, potato market, European integration JEL codes: Q11, Q13

\section{INTRODUCTION}

Despite the favourable soil quality and favourable climatic conditions for the growth of root crops in Poland, since the early nineties, we have seen a sharp decline in their harvest and crop area. The number of growers also decreased significantly (Czakowski and Czyżewski, 2017), which is typical for many countries from Eastern Europe after the collapse of socialism (Prishchepov et al., 2012). A characteristic feature of root crops, in comparison to other field crops, is high capital intensity and labour consumption of production. In addition, they require planting at large intervals from each other, due to the large yield. Although many plants include rooted sunflower, swede, carrot, chicory, fodder beets, and turnip, trench crops are the key factors in the structure of crops in Poland in potatoes and sugar beets (Stańko, 2013). The aim of this study is to identify the dynamics and direction of the root plants market in Poland, taking into account the similarities and differences between the potato and sugar beet markets, in the period before and after accession to the European Union. This will be achieved by the determination of production results and the dynamics of prices and incomes on the potato and sugar beet market.

${ }^{1}$ Corresponding author: Podgórna 50, building A-O, 65-246 Zielona Góra, a.czyzewski@wez.uz.zgora.pl, +4868 3282555

${ }^{2}$ Corresponding author: Toruńska 55-57, 85-023 Bydgoszcz, Poland, d.czakowski@kpsw.edu.pl, +4852 3211188 


\section{THEORETICAL BACKGROUND}

This article is part of the canon of works related to the issue of state interference in free market economy. Due to the fact that agriculture is included in the real economy sphere, the change of its institutional and economic environment as well as broad financial support should determine its permanent structural transformations (Poczta, 2009). However, due to the specific dissimilarity of this sector from other branches of the national economy, conditioned primarily by the compulsion of food consumption and specificity, a key production factor in agriculture, which is land, adaptation processes in the agricultural sector are difficult (Tilman et al., 2002; Czyżewski and Matuszczak, 2011). It is worth adding that despite fears Polish agriculture turned out to be competitive within the EU (Gorton et al., 2001; Wigier, 2014).

\section{MATERIALS AND METHODS}

The research was carried out in the years 1994-2016. The choice of a relatively long period was associated with an attempt to show the adjustments that took place on the markets surveyed in the period after Poland's accession to the European Union. The source data used in the work came from the Institute of Agricultural Economics and Food Economy and the Central Statistical Office. Purchase prices for potatoes and sugar beet as well as the financial results of agricultural holdings have been expressed in real prices, i.e. nominal prices adjusted by the consumer price index of goods and services. The base year was adopted in 2016. To achieve the intended research goal, among others dynamic indexes (used to compare the phenomena discussed in time) and analysis of Pearson's linear correlation, which allowed to determine the strength, direction and significance of relationships between selected variables related to the cultivation of potatoes and sugar beet. Using cost-absorption ratios, calculated as the ratio of total costs to production value and income efficiency, which was defined as the ratio of income from activity to total costs, the effectiveness relations were determined.

\section{RESULTS AND DISCUSSION}

The abolition of trade barriers between Poland and EU countries led to the harmonization of the price level between the domestic and EU agricultural market, and also guaranteed greater stabilization (Czakowski, 2017). In 2016, real purchase prices of potatoes were $41 \%$ lower than in 1994 (Fig. 1). It is worth noting that potato prices grew very quickly in 1991-1994, not included in the analysis, faster than in the case of cereals. This accelerated the process of replacing potatoes as animal feed by crop plants (Chotkowski, 2008). On the other hand, real purchase prices of sugar beets decreased by $35 \%$ in the analysed period. It is worth mentioning that due to the numerous regulations on the sugar market, sugar beet prices were also dependent on intervention policy instruments. The effect of these activities was visible in 2004, when after the accession to the EU there was a sharp increase in sugar beet prices in Poland, due to the need to adjust domestic prices to the minimum prices in the Community (Hryszko and Szajner, 2013).

On the potato market in Poland in the post-accession period there was a significant decrease in the average annual crop area (Table 1). In addition, the average annual size of potato harvests dropped significantly with relatively small increase in average annual yield. The above changes are the effect of declining demand. The demand for potatoes for feeding them was the most drastic. Due to low prices on meat markets and pressure to optimize costs, they have become an expensive way to provide nutritional value in relation to feed grains (Czakowski, 2016). In addition, consumer demand has also decreased. It is worth notice that this was determined by the drop in the consumption of unprocessed potatoes, whose increase in processed food consumption was not able to compensate.

The scale of sugar beet cultivation in the analysed period was determined by a number of regulations and instruments on the sugar market, which include, inter alia: production quotas, duties, income support for growers. The reform of the 2006/2007 season was particularly important, as a result of which the number of sugar factories in Poland decreased from 
Proceedings of the 2018 International Scientific Conference 'Economic Sciences for Agribusiness and Rural Economy' No 2, Warsaw, 7-8 June 2018, pp. 231-237

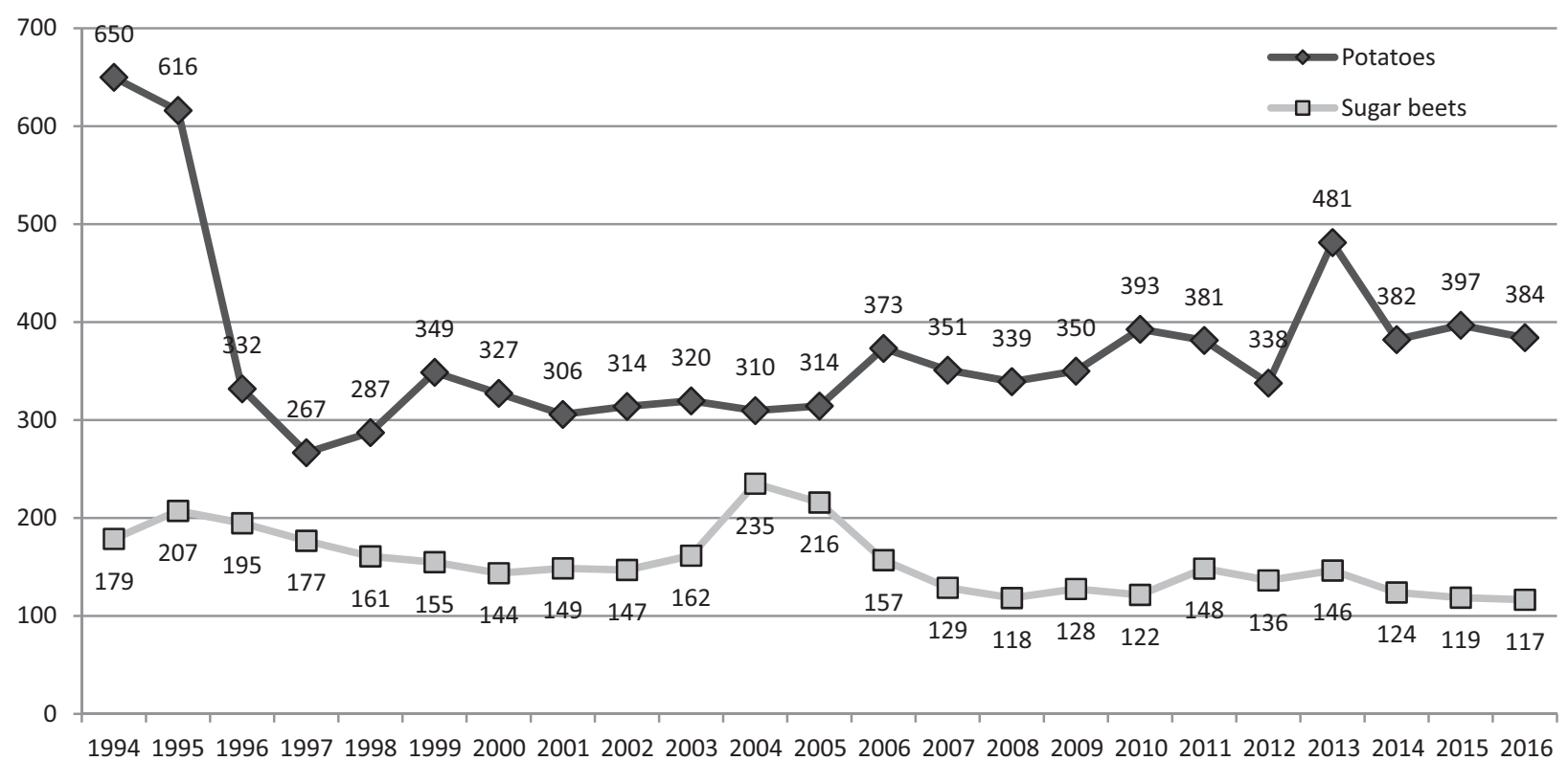

Figure 1. Purchase prices of potatoes and sugar beets in Poland in 1994-2016 (base year =2016)

Source: GUS (1995-2017).

Table 1. Average annual area of cultivation, yield, and harvest of potatoes and sugar beet in Poland in 2004-2016

\begin{tabular}{|l|c|c|c|c|c|c|}
\hline \multirow{2}{*}{ Specification } & Potatoes & \multicolumn{5}{|c|}{ Sugar beets } \\
\cline { 2 - 7 } & $\begin{array}{c}\text { area of } \\
\text { cultivation } \\
\text { (thous. ha) }\end{array}$ & $\begin{array}{c}\text { crops } \\
\text { (tonne/ha) }\end{array}$ & $\begin{array}{c}\text { harvest } \\
\text { (million } \\
\text { tonnes) }\end{array}$ & $\begin{array}{c}\text { cultivation } \\
\text { area } \\
\text { (thous. ha) }\end{array}$ & crops (t/ha) & $\begin{array}{c}\text { harvest } \\
\text { (million } \\
\text { tonnes) }\end{array}$ \\
\hline $\begin{array}{l}\text { Average for years } \\
\text { 1994-2003 (1) }\end{array}$ & 1244.40 & 174.70 & 21.47 & 366.70 & 353.30 & 13.61 \\
\hline $\begin{array}{l}\text { Average for years } \\
\text { 2004-2016 (2) }\end{array}$ & 453.85 & 213.62 & 9.40 & 216.46 & 540.15 & 11.53 \\
\hline $\begin{array}{l}\text { Dynamics index (2)/(1) } \\
(1994-2003=100)\end{array}$ & 36 & 122 & 44 & 59 & 153 & 85 \\
\hline
\end{tabular}

Source: GUS (1994-2016).

78 to 18 , and the production limit was introduced. In relation to the above, the sugar market in Poland has the structure of a classic oligopoly (Szajner, 2014). Sugar beet harvest in 2004-2016 was 15\% lower than in the period 1994-2003. This indicates that the increase in yield did not compensate for the reduction in production as a result of a smaller crop area, but still Poland is one of the top producers of sugar in EU (Smit et al., 2017).
Financial results of farms clearly indicate that the increase in the income from producers activity on the sugar beet market was affected by subsidies stimulating production (Czakowski, 2015). Without them, the producers' income in the post-accession period, just like on the potato market, would be smaller than before accession (Fig. 2).

It is also worth notice that on the potato market the real costs as well as the value of production increased 


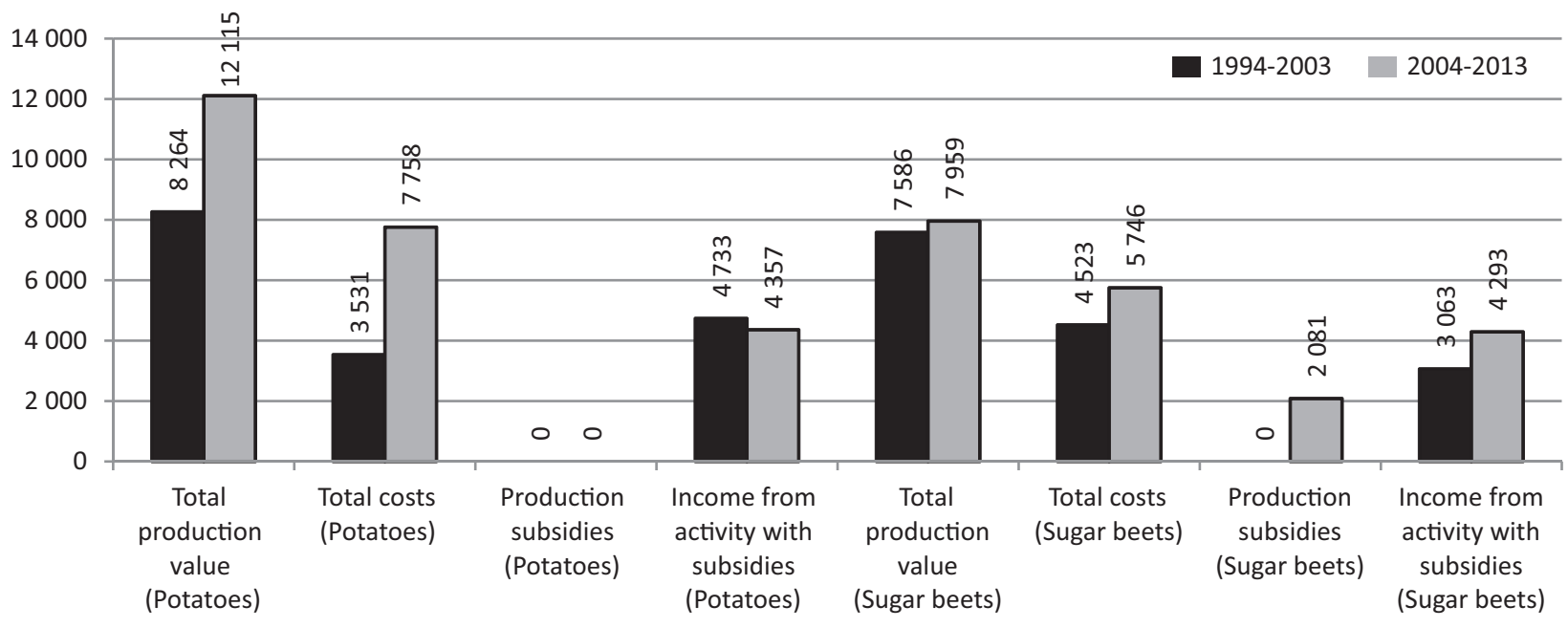

Figure 2. Financial results of farms growing potatoes and sugar beet in Poland in the years 1994-2003 and 2004 -2016 (in PLN per 1 ha of crops, base year $=2016$ )

Source: own study based on FADN data.

at the same time, which at the same time worsened the relation of income to costs. In both markets under review during the post-accession period, the average annual values of cost-consumption coefficients and income efficiency (excluding production subsidies) were less favourable than before (Table 2). This is due to the so-called technological treadmill. This mechanism forces farmers to constantly increase la- bour productivity leading to cost reduction, which in turn does not translate into an increase in income due to declining prices of agricultural raw materials (Czyżewski and Czyżewski, 2015).

Among many interesting compounds presented in Table 3, it is worth pointing out that both in the period before and after the accession, there were positive correlation relationships between the income

Table 2. Cost-absorption and income efficiency of potato and sugar beets cultivation in Poland in the years 1994-2003 and 2004-2016

\begin{tabular}{|l|c|c|c|c|c|}
\hline \multirow{2}{*}{ Specification } & \multicolumn{2}{|c|}{ Potatoes } & \multicolumn{2}{c|}{ Sugar beets } \\
\cline { 2 - 5 } & Cost-absorption* & $\begin{array}{c}\text { Income } \\
\text { efficiency** }\end{array}$ & Cost-absorption* & $\begin{array}{c}\text { Income } \\
\text { efficiency** }\end{array}$ & $\begin{array}{c}\text { Income efficiency } \\
\text { w/o subsidies for } \\
\text { production }\end{array}$ \\
\hline $\begin{array}{l}\text { Average for years } \\
1994-2003(1)\end{array}$ & 0.44 & 1.38 & 0.61 & 0.7 & 0.7 \\
\hline $\begin{array}{l}\text { Average for years } \\
\text { 2004-2016 (2) }\end{array}$ & 0.65 & 0.57 & 0.77 & 0.73 & 0.37 \\
\hline $\begin{array}{l}\text { Dynamics index (2)/(1) } \\
(1994-2003=100)\end{array}$ & 148 & 42 & 127 & 104 & 53 \\
\hline
\end{tabular}

${ }^{*}$ Cost-absorption: Total cost / value of production; ${ }^{* *}$ Income efficiency: total income / costs; ${ }^{* * *}$ Income efficiency without subsidies for production: income without subsidies for production / total costs

Source: own study based on FADN data. 
Table 3. Values of Pearson's linear correlation coefficients related to selected variables related to the cultivation of potatoes and sugar beet in Poland in the years 1994-2003 and 2004-2016

\begin{tabular}{|l|l|c|c|}
\hline \multicolumn{1}{|c|}{ Variable 1 } & \multicolumn{1}{c|}{ Variable 2 } & 1994-2003* & 2004-2016* \\
\hline \multirow{5}{*}{ Harvest (Potatoes) } & Harvest (Sugar beets) & 0.55 & 0.27 \\
\cline { 2 - 4 } & Area of cultivation (Potatoes) & 0.78 & 0.85 \\
\cline { 2 - 4 } & Crops (Potatoes) & -0.45 & -0.74 \\
\cline { 2 - 4 } & Purchase price (Potatoes) & -0.53 & -0.73 \\
\cline { 2 - 4 } & Income efficiency (Potatoes) & 0.63 & 0.23 \\
\hline \multirow{3}{*}{ Harvest (Sugar beets) } & Area of cultivation (Sugar beets) & 0.73 & 0.02 \\
\cline { 2 - 4 } & Crops (Sugar beets) & 0.27 & 0.28 \\
\cline { 2 - 4 } & Purchase price (Sugar beets) & -0.1 & 0.64 \\
\cline { 2 - 4 } & Income efficiency (Sugar beets) & 0.44 & 0.80 \\
\hline Area of cultivation (Potatoes) & Area of cultivation (Sugar beets) & 0.79 & 0.88 \\
\hline Crops (Potatoes) & Crops (Sugar beets) & 0.2 & -0.46 \\
\hline Purchase price (Potatoes) & Purchase price (Sugar beets) & 0.35 & 0.11 \\
\hline Income efficiency (Potatoes) & Income efficiency (Sugar beets) & 0.93 & 0.51 \\
\hline
\end{tabular}

${ }^{*}$ The correlation coefficient is statistically significant $(\mathrm{p}=0.05$, for $n=10$ the critical value is 0.6319 , for $n=13$ the critical value is 0.5529 ).

Source: own study based on FADN and Central Statistical Office (GUS) data, the calculations were made using the Statistica 12.

efficiency of production and the size of the collections in both examined markets. However, these interdependencies were characterized by significant linear correlation coefficients, in the case of the potato market in the pre-accession period (there was a significant decrease in production, which was caused by decreasing profitability of crops), and in the case of sugar beet in the post-accession period (impact of subsidies on production volume). It is worth adding that the main determinant of the size of potato harvest in 2004-2016 was the area of cultivation, whereas the sugar beet harvest was not significantly interrelated, either with the crop area or with the level of yield (Czyżewski and Czakowski, 2018). This can be explained by extensive interventional mechanisms on this market, which were not so important in the case of potatoes. In turn, between the purchase prices and the size of harvests on the potato market in both analysed periods, there was a significant negative correlation relationship. Therefore, it can be concluded that producers in this market were not able to react to price changes on an ongoing basis, and additionally shortages/overproduction contributed to their fluctuations.

Between the cultivated area and the yield (except for the pre-accession period), significant and positive correlation relationships occurred in both markets, which was related to similar cultivation technology and a nationwide tendency to reduce the area of cultivation (Czyżewski and Czakowski, 2017). On the other hand, the development of procurement prices and the efficiency ratio was characterized by the lack of significant correlation relationships between the markets surveyed markets in the post-accession period, with simultaneous significant correlation between the income-efficiency ratios in the pre-accession period. This can be explained first of all by the differences in the formation of world prices and more extensive mechanisms of support and regulation of the sugar and sugar beet market. 


\section{CONCLUSIONS}

1. Poland's accession to the European Union accelerated the processes of concentration and specialization of production. This was done at the expense of a significant reduction in the area of crops and the number of small growers. In the case of sugar beet cultivation, this process accelerated due to the introduction of new regulations on the sugar market, which coincided with the first years of Poland's membership in the EU.

2. In the post-accession period, the formation of purchase prices on the potato and sugar beet market was more dependent on the level of world prices, due to the accession to the single European market. In addition, the level of domestic prices was also dependent on the mechanisms of the common agricultural policy, which was especially visible on the sugar beet market, where in the first two years of membership there were significant increases related to the adjustment of minimum purchase prices to those applicable in the EU. On the other hand, the reform of the sugar market from the 2006/2007 season resulted in a reduction in sugar beet prices.

3. One of the most important aspects related to the accession for agricultural producers were subsidies in various forms to their activities. They had a significant impact on the production profitability, especially on the sugar beet market, where they occurred in the form of subsidies for production. On the potato market producers could not count on similar discounts. Other subsidies, such as uniform area payments, payments for greening and additional payments. Nevertheless, in the postaccession period, the income from the activity of potato producers increased, with a simultaneous slight decrease in cost-efficiency and income efficiency. On the other hand, in the case of sugar beets, both the profitability of production (income) and cost-consumption and income-efficiency indicators decreased.

4. There is a significant difference between the examined markets in the impact of the Common Agricultural Policy mechanisms in the post-accession period. This could have an impact on the lack of a significant correlation relationship between potato harvests and the income efficiency ratio in the post-accession period (while in the pre-accession period such a relationship occurred). On the other hand, the reverse situation took place on the sugar beet market, significant interdependence between these features occurred in the post-accession period, and before the accession it was not recorded.

\section{REFERENCES}

1. Chotkowski, J. (2008). Perspektywy produkcji ziemniaków w Polsce w opiniach przedsiębiorstw nasiennych [Prospects for potato production in Poland in the opinions of seed companies]. Biuletyn Instytutu Hodowli i Aklimatyzacji Roślin, 242, pp. 153-154.

2. Czakowski, D. (2015). Rynek roślin okopowych w Polsce: poziom, dynamika i uwarunkowania rozwoju [Root plants market in Poland: level, dynamics and determinants of development]. Zeszyty Naukowe Uniwersytetu Szczecińskiego, 41 (2), pp. 147-157.

3. Czakowski, D. (2016). Tendencje w kształtowaniu się cen skupu podstawowych produktów roślinnych przed i po akcesji Polski do Unii Europejskiej (1994-2013) [Trends in the formation prices of basic plant products before and after Poland's accession to the European Union (1994-2013)]. Roczniki Ekonomicze Kujawsko-Pomorskiej Szkoły Wyższej Bydgoszczy, Bydgoszcz.

4. Czakowski, D. (2017). Konkurencyjność międzynarodowa podstawowych produktów rolnych w Polsce przed i po akcesji do Unii Europejskiej (1994-2013) [International competitiveness of basic agricultural products in Poland before and after accession to the European Union (1994-2013)]. Roczniki Ekonomiczne Kujawsko-Pomorskiej Szkoły Wyższej w Bydgoszczy, Bydgoszcz.

5. Czakowski, D., Czyżewski, A. (2017). Podstawowe rynki rolne w Polsce przed i po akcesji do Unii Europejskiej. Poziom i uwarunkowania rozwoju [Basic agricultural markets in Poland before and after accession to the European Union. Level and conditions of development]. Kujawsko-Pomorska Szkoła Wyższa w Bydgoszczy, Bydgoszcz.

6. Czyżewski, A., Czakowski, D. (2017). Changes in Agricultural Markets in Poland follow in its Accession to the European Union. Management, 21 (2), pp. 138-150. 
7. Czyżewski, A., Czakowski, D. (2018). Similarities and differences in the core markets for agricultural products in Poland after the accession to the European Union. Journal of Agribusiness Rural Development, 1 (47), pp. 13-19.

8. Czyżewski A., Czyżewski B. (2015). Ziemia i jej renty w nowym paradygmacie rozwoju rolnictwa [Land and its rent in a new paradigm of agricultural development]. In: Czyżewski, A., Klepacki, B. (eds.) Problemy rozwoju rolnictwa i gospodarki żywnościowej w pierwszej dekadzie członkostwa Polski w Unii Europejskiej [Problems of agriculture development and food economy in the first decade of Poland's membership in the European Union]. PTE, Warszawa.

9. Czyżewski, A., Matuszczak, A. (2011). Dylematy kwestii agrarnej w panoramie dziejów [Dilemmas of the agrarian issue in the panorama of history]. Zeszyty Naukowe SGGW w Warszawie. Ekonomika i Organizacja Gospodarki Żywnościowej, 90, pp. 14-16.

10. FADN Poland (n.d.). Szeregi czasowe. Retrieved from: http://fadn.pl/publikacje/szeregi-czasowe [Accessed 15.04.2018].

11. GUS (1994-2016). Rocznik Statystyczny Rzeczypospolitej Polskiej (dane za lata 1994-2016) [Statistical Yearbook of the Republic of Poland (data for the years 1994-2016)]. Dział Wydawnictw Statystycznych, Warszawa.

12. GUS (1995-2017). Skup i ceny produktów rolnych (dane za lata 1994-2016) [Purchase and prices of agricultural products (data for 1994-2016)]. Dział Wydawnictw Statystycznych, Warszawa.

13. Gorton, M. et al. (2001). The international competitiveness of Polish agriculture. Post-communist Economies, 13 (4), pp. 445-457.

14. Hryszko K., Szajner P. (2013). Sytuacja na światowym rynku cukru i jej wpływ na możliwości uprawy buraków cukrowych w Polsce [The situation on the global sugar market and its impact on the possibilities of growing sugar beet in Poland]. IERiGŻ-PIB, Warszawa.

15. Poczta, W. (2009). Wpływ integracji z UE na sytuację strukturalną, produkcyjną i ekonomiczną polskiego rolnictwa [Impact of integration with the EU on the structural, production and economic situation of Polish agriculture]. In: Urban, R. (ed.) Stan polskiej gospodarki żywnościowej po przystąpieniu do Unii Europejskiej [The state of the Polish food economy after joining the European Union]. IERiGŻ-PIB, Warszawa, pp. 9-47.

16. Prishchepov, A.V. et al (2012). Effects of institutional changes on land use: agricultural land abandonment during the transition from state-command to marketdriven economies in post-Soviet Eastern Europe. Environmental Research Letters, 7 (2), pp. 3-4.

17. Smit, A.B. et al. (2017). Impact of coupled EU support for sugar beet growing: more production, lower prices. Wageningen Economic Research, 114, p. 18.

18. Stańko, S. (2013). Zmiany i projekcje rozwoju na podstawowych rynkach rolnych w Polsce [Changes and development projections on basic agricultural markets in Poland]. Wydawnictwo SGGW, Warszawa.

19. Szajner, P. (2014). Wpływ sytuacji na rynku na krajowy rynek produktów rolno-żywnościowych [Impact of the market situation on the domestic market of agri-food products]. In: Szajner, P. (ed.) Monitoring rynków rolno-spożywczych w warunkach zmieniającej się sytuacji ekonomicznej. Synteza wyników z badań [Monitoring of agri-food markets in the conditions of a changing economic situation. Synthesis of test results]. IERiGŻ-PIB, Warszawa, pp. 20-21.

20. Tilman, D. et al. (2002). Agricultural sustainability and intensive production practices. Nature. No 418.6898, pp. 671-677.

21. Wigier, M. (2014). The competitiveness of Polish agriculture after accession to the EU. Economics of Agriculture, 1, pp. 87-102. 